\title{
Derek Denny-Brown: the man behind the ganglia
}

\section{Derek Denny-Brown: o homem por detrás dos gânglios}

Alberto R. M. Martinez', Ingrid Faber', Carlos Roberto Martins Jr', Raphael F. Casseb ${ }^{1}$, Anamarli Nucci', Marcondes C. França Jr'1, Hélio A. G. Teive ${ }^{2}$

\section{ABSTRACT}

The authors present an historical review about the main contributions of Professor Derek Denny-Brown to neurology. Some of his achievements include the first description of sensory neuronopathies, and some of the essential textbooks on the function and anatomy of the basal ganglia. In 2016, on the 35th anniversary of his death, modern neurologists are still strongly influenced by his legacy.

Keywords: Denny-Brown; neurology; ganglia, spinal; basal ganglia; movement disorders.

\section{RESUMO}

Os autores apresentam uma revisão histórica sobre as principais contribuições do Professor Derek Denny-Brown à neurologia. Suas realizações incluem a primeira descrição da neuronopatia sensitiva e alguns dos livros fundamentais acerca da função e anatomia dos núcleos da base. Em 2016, ano do seu $35^{\circ}$ aniversário de falecimento, os neurologistas atuais ainda são fortemente influenciados pelo seu legado.

Palavras-chave: Denny-Brown; neurologia; gânglios espinais; gânglios da base; transtornos dos movimentos.

One hundred and fifteen years after his birth in New Zealand (June $1^{\text {st }}, 1901$ ) and 35 years after his death (April 20 2 th 1981 ), the accomplishments and scientific work of Derek Ernest Denny-Brown (Figure) are a strong foundation for several neurological advances, even in the present day ${ }^{1,2}$. With his legacy of dozens of published papers and books, he has made substantial contributions toward a better understanding of the basal ganglia's functions and structure ${ }^{1,3,4}$. He was also the first to describe sensory neuronopathy ${ }^{5}$. In fact, he contributed in so many fields in neurology that it would be unfair and impossible to point out only a few.

\section{SHORT BIOGRAPHY}

After earning his medical degree in New Zealand and initially seeking a better understanding of postural control, Denny-Brown moved to Oxford where he delved deeper into neurophysiology research carried out under the mentorship of Sir Charles Sherrington. Later, in 1928, after being awarded his $\mathrm{PhD}$, he decided to return to clinical practice, applying for a post as a house physician. In December of the same year, he began his work as a resident medical officer

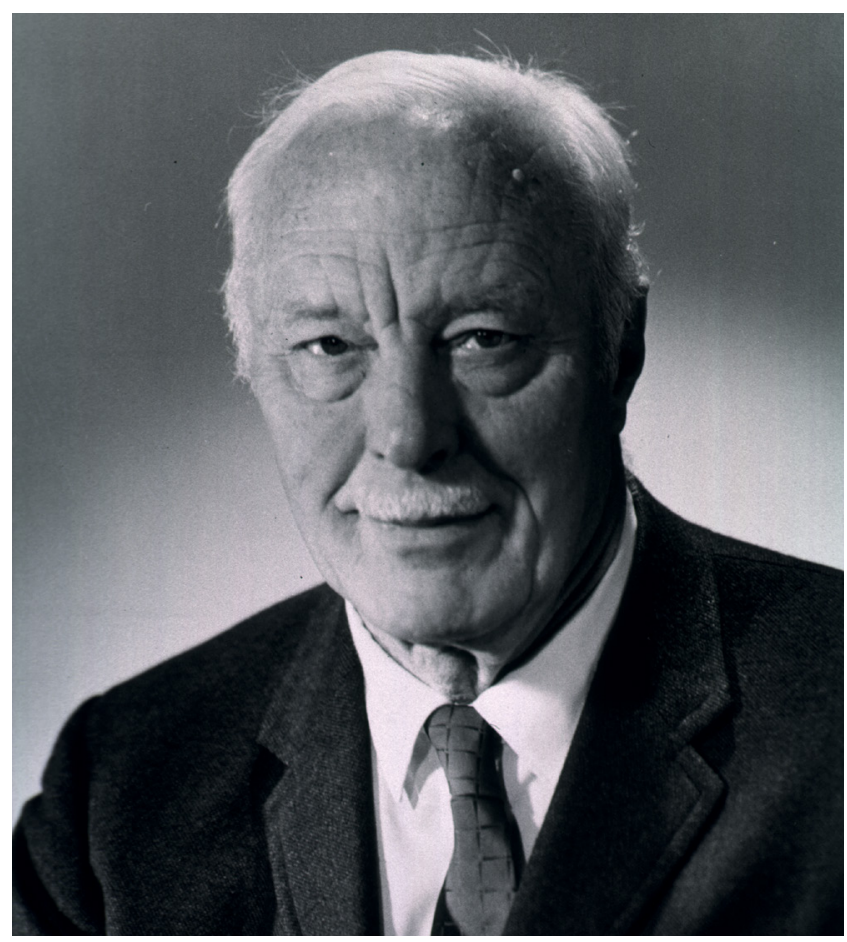

(Image in the public domain. Reproduced from The National Library of Medicine http://collections.nlm.nih.gov).

Figure. Derek Denny-Brown (1901-1981).

1 Universidade Estadual de Campinas, Departamento de Neurologia, Campinas SP, Brasil;

${ }^{2}$ Universidade Federal do Paraná, Hospital de Clínicas, Departamento de Medicina Interna, Serviço de Neurologia, Unidade de Distúrbios dos Movimentos, Curitiba PR, Brasil.

Correspondence: Alberto R.M. Martinez; Rua Tessália Vieira de Camargo, 126; Cidade Universitária "Zeferino Vaz"; $130083-970$ Campinas SP, Brasil; E-mail: albertommartinez@yahoo.com.br 
at the National Hospital, Queen Square ${ }^{1}$. During the following years, he had some great medical bulwarks as teachers, supervisors and colleagues, including Drs. William Adie, MacDonald Critchley, Charles Symonds, Gordon Holmes, Kinnier Wilson, Francis Walshe and James Collier ${ }^{1}$. For the next 11 years he continued working in London at Queen Square, where he introduced electromyography and muscular biopsy as tools in neuromuscular investigation ${ }^{1}$. During World War II, he served as a physician in the Royal Army Medical Corps from 1939 to 1941, until James Conant, the President of Harvard University at that time, requested to Sir Winston Churchill to release Denny-Brown from duty. This allowed his transfer to Boston.

In 1946, Denny-Brown assumed the position of Professor of Neurology at Harvard Medical School and Director of Harvard's Neurological Unit at the Boston City Hospital, chairs he held until his retirement in $1967^{1,4}$.

\section{DENNY-BROWN “SELF-EXPERIMENTATION”}

His commitment and eagerness for science and research are shown in two solid examples of peculiar and almost mythical stories. First, in order to evaluate and describe the phenomena of micturion reflexes, he and Graeme Robertson used themselves as subjects in what Robertson described years later as an "intimate scientific association". Second, and no less impressive, is that, with the impending amputation of his third finger due to a severe Dupuytren's contracture, Denny-Brown induced a digital nerve injury to experience the symptoms of post-traumatic neuralgia. He later described his findings in a paper published in Brain ${ }^{7}$.

\section{Denny-Brown and the dorsal root ganglia}

It was in 1939 that two patients crossed Denny-Brown's path, resulting in one of his most remarkable accomplishments - the first description of sensory neuronopathies. Both patients presented with sensory ataxia, with a sensory loss following a non-length-dependent and asymmetric pattern. With his analytical mindset, Denny-Brown identified the commonalities between the two cases: a massive destruction of the dorsal root ganglia, polymyositis and bronchial carcinoma. At that time, he attributed the disease to metabolic consequences of the neoplasm. Even though today it is known that the etiology of the dorsal root ganglion damage is not attributable simply to metabolic issues, Denny-Brown's work stands as the first description of sensory ataxia due to dorsal root ganglion injury, also known as Denny-Brown's syndrome ${ }^{5}$. It is important not to confuse this entity with the Denny-Brown and Foley's syndrome, which is related to benign fasciculations ${ }^{8}$.

\section{Denny-Brown and the Basal Ganglia}

Some other remarkable achievements were made by Denny-Brown towards the better understanding of the basal ganglia and their influence on movement disorders. In fact, between the 1940s and 1960s, he published the three classical books regarding this topic: Diseases of the Basal Ganglia and Subthalamic Nuclei(1946), The Basal Ganglia (1962) and The Cerebral Control of Movement $(1966)^{1,2,4}$. In these books, for the first time, Denny-Brown went into deep discussion of the anatomy and physiology of the basal ganglia and several types of movement disorders, such as tremor, chorea, athetosis, dystonia, and parkinsonism ${ }^{1,4}$. In his most famous book The Basal Ganglia and Their Relation to Disorders of Movement, he also evaluated the classical diseases, including hepatolenticular degeneration (Wilson's disease), Huntington's chorea, dystonia musculorum deformans, and Hallerworden-Spatz syndrome, among others ${ }^{4}$. Finally, he presented his experimental lesions of the basal ganglia in monkeys, particularly in the caudate nucleus, putamen, and globus pallidus ${ }^{4}$. The impressive amount of experimental data involving about 450 monkeys, acquired during his lifetime and especially during the period after his "retirement" from clinical practice (1967), when he worked at the New England Regional Primate Research Center, was published just before his death in $1981^{2}$.

It is well known that, for the first time in the world, Denny-Brown used the expression "disorders of movement" (nowadays movement disorders), instead extrapyramidal syndromes ${ }^{3,4,9}$.

\section{CONCLUSION}

Even after his death from multiple myeloma, DennyBrown's legacy continued in the memory of his wife Sylvia Summerhayes and their four sons, as well as in the annals of modern neurology ${ }^{1}$. He is known as one of the most embattled defenders of neurology as a distinct specialty. In his famous paper: The Changing Pattern of Neurologic Medicine he stated that "...equipped with a special knowledge of the vagaries of neurological disorders and their underlying pathology and with a flexibility of investigative technique, the neurologist has no difficulty in holding his own in a changing world..."10.

Denny-Brown impressed not only his trainees, who later became neurology advocates, but also names like Gordon Holmes, who wrote a letter to Denny-Brown in the 1950s that read: "I have had many letters of congratulations on my $80^{\text {th }}$ birthday, but not one pleased me more than that from you. Rosalie truthfully said that I became quite emotional in reading it. It at least has made me feel that my work at Queen Square has not been wasted...". 


\section{References}

1. Foley JM. Derek Denny-Brown, 1901-1981. Ann Neurol. 1982;11(4):413-9. http://doi.org/10.1002/ana.410110416

2. Vilensky JA, Gilman S. The Denny-Brown collection. Neurology. 1990;40(10):1636.

3. Denny-Brown D. Diseases of the basal ganglia: their relation to disorders of movement. Lancet. 1960;276(7161):1155-62. http://doi.org/10.1016/S0140-6736(60)92353-9

4. Denny-Brown D. The basal ganglia and their relation to disorders of movement.. London: Oxford University Press; 1962. (Oxford Neurological Monographies)

5. Denny-Brown D. Primary sensory neuropathy with muscular changes associated with carcinoma.J Neurol Neurosurg Psychiatry. 1948;11(2):73-87.
6. Vilensky JA, Bell DR, Gilman S. "On the physiology of micturition" by Denny-Brown and Robertson: a classic paper revisited. Urology. 2004;64(1):182-6. http://doi.org/10.1016/S0090-4295(03)00341-8

7. Denny-Brown D. The release of deep pain by nerve injury. Brain. 1965;88(4):725-8. http://doi.org/10.1093/brain/88.4.725

8. Denny-Brown D, Pennybacker JB. Fibrillation and fasciculation in voluntary muscle. Brain. 1938;61(3):311-2. http://doi.org/10.1093/brain/61.3.311

9. Denny-Brown D. The nature of dystonia. Bull N YAcad Med. 1965;41(8):858-69.

10. Denny-Brown D. The changing pattern of neurologic medicine. N Engl J Med. 1952;246(22):839-46. http://doi.org/10.1056/NEJM195205292462201 